\title{
Regulation of the gene encoding translation elongation factor 3 during growth and morphogenesis in Candida albicans
}

\author{
R. K. Swoboda, ${ }^{1} \dagger$ G. Bertram, ${ }^{1}$ D. R. Colthurst, ${ }^{2}$ M. F. Tuite, ${ }^{2}$ \\ N. A. R. Gow, ${ }^{1}$ G. W. Gooday ${ }^{1}$ and A. J. P. Brown ${ }^{1}$
}

Author for correspondence: A. J. P. Brown. Tel: +44224 273183. Fax: +44224273144.

\footnotetext{
1 Molecular and Cell Biology, University of Aberdeen, Marischal College, Aberdeen AB9 1AS, UK

2 Biological Laboratory, University of Kent, Canterbury, Kent CT2 7NJ, UK
}

\begin{abstract}
The level of the TEF3 mRNA, which encodes the fungal-specific translation elongation factor 3 (EF-3), was measured during the yeast-to-hyphal transition in Candida albicans. In contrast to a previous report, TEF3 mRNA levels were shown to change during dilution into fresh medium, increasing only transiently when dimorphism was induced by either (i) an increase in growth temperature (from $25^{\circ} \mathrm{C}$ to $37^{\circ} \mathrm{C}$ ) combined with the addition of $10 \%(\mathrm{v} / \mathrm{v}$ ) bovine calf serum to the medium, or (ii) an increase in growth temperature (from $25^{\circ} \mathrm{C}$ to $37^{\circ} \mathrm{C}$ ) combined with an increase in the pH of the medium (from pH 4.5 to 6.5). TEF3 mRNA levels also increased in control cultures under conditions where germ tubes were not formed, but they remained elevated in contrast to cultures undergoing morphological changes. TEF3 mRNA levels were not significantly affected by heat-shock, but were tightly regulated during batch growth of the yeast form, reaching maximal levels in exponential phase. Therefore, the changes in TEF3 expression that accompany the dimorphic transition in C. albicans appear to reflect the underlying physiological changes that occur during morphogenesis and are not a response to morphogenesis per se. For this reason TEF3 mRNA measurement cannot be used as a loading control in Northern analyses of dimorphic gene regulation. Comparison of TEF3 mRNA levels with the abundance of the EF-3 polypeptide indicated that the synthesis of this essential translation factor might be subject to post-transcriptional regulation.
\end{abstract}

\section{Keywords: Candida albicans, translation elongation factors, TEF3 regulation,} dimorphism, heat-shock

\section{INTRODUCTION}

Candida albicans most frequently infects the mucous epithelial tissues of the oral and urogenital tracts, but in the immunocompromised host it can cause deep-seated and systemic infections (Odds, 1988). A number of factors are thought to influence the pathogenicity of this fungus (for reviews see Cutler, 1991; Odds, 1988), one of which is its ability to undergo a dimorphic switch from a budding yeast to a hyphal form (for reviews see Gow \& Gooday, 1987; Odds, 1985; Soll, 1986). Although both yeast and hyphal cells can be observed in infected tissue (Odds, 1988), and the yeast form is pathogenic under some experimental conditions (Ryley \& Ryley, 1990), C. albicans hyphae appear better adapted to penetrate epithelia

†Present address: Hans Knöll Institut für Naturstoff-Forschung, 07745 Jena, Germany.
(Sherwood et al., 1992), suggesting that dimorphism is an important aspect of pathogenicity in vivo.

Translational elongation in eukaryotic organisms is dependent upon the two soluble elongation factors EF-1 and EF-2, which are functionally analogous to the prokaryotic factors EF-Tu and EF-G, respectively (for reviews see Hinnebusch \& Liebman, 1991; Merrick, 1992; Nygard \& Nilsson, 1990; Tuite, 1989). However, a third elongation factor (EF-3) is required for translation in fungi (for review see Belfield \& Tuite, 1993). EF-3, which was first identified in Saccharomyces cerevisiae (Skogerson \& Wakatama, 1976), has now been observed in numerous fungi including Schizosaccharomyces pombe (Uritani \& Miyazaki, 1988), Pneumocystis carinii (YpmaWong et al., 1992), and several Candida species (Chakraburtty \& Kamath, 1988; Colthurst et al., 1991). Although the precise function of EF-3 has not been 
(a)

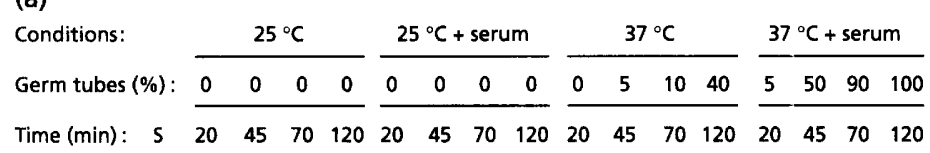

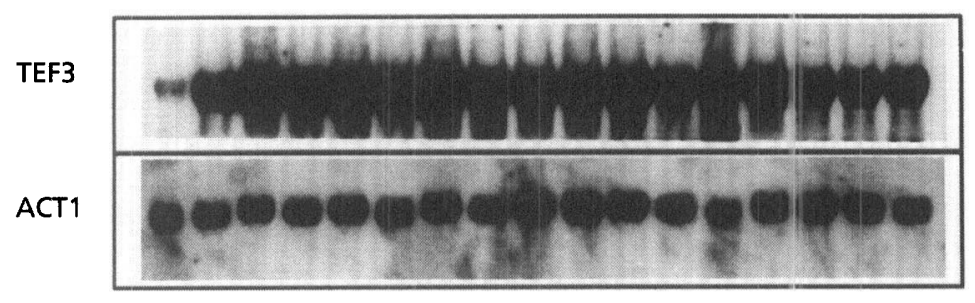

(b)

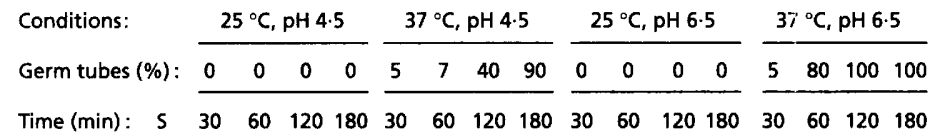
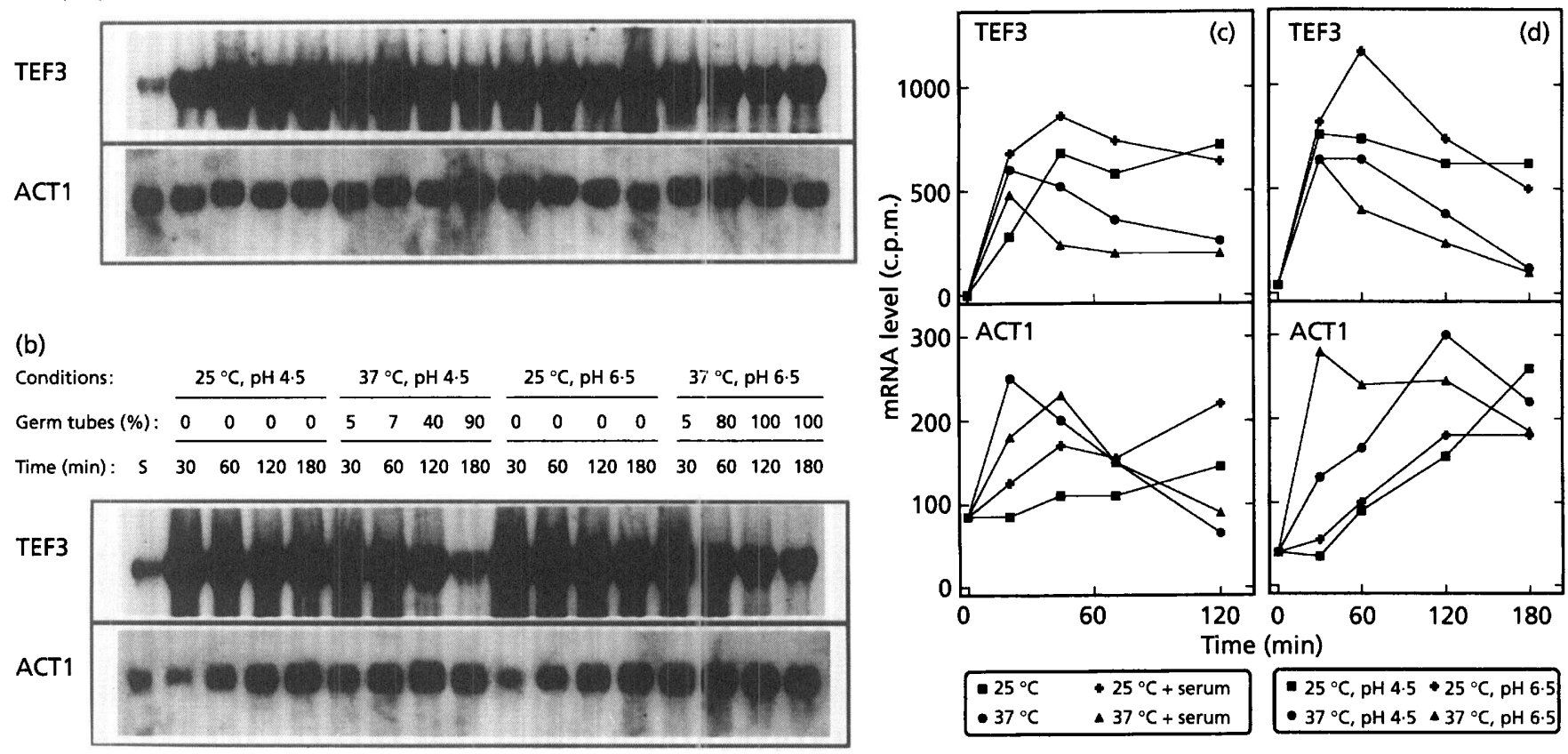

$25^{\circ} \mathrm{C}, \mathrm{pH} 4.5+25^{\circ} \mathrm{C}, \mathrm{pH} 6.5$ $-37^{\circ} \mathrm{C}, \mathrm{pH} 4.5-37^{\circ} \mathrm{C}, \mathrm{pH} 6.5$

Fig. 1. TEF3 mRNA levels during the yeast-to-hyphal transition. (a) An overnight starter culture of $C$. albicans (S) grown in YPD at $25^{\circ} \mathrm{C}$ was used to inoculate flasks containing either YPD at $25^{\circ} \mathrm{C}$, YPD containing serum at $25^{\circ} \mathrm{C}$, YPD at $37^{\circ} \mathrm{C}$, or YPD containing serum at $37^{\circ} \mathrm{C}$, and the proportion of cells forming germ tubes in each culture was estimated by light microscopy. The levels of the TEF3 and ACT1 mRNAs were measured at various times (min) thereafter by quantitative Northern analysis. (b) An overnight starter culture of $C$. albicans (S) grown in Soll's Medium at pH 4.5 and $25^{\circ} \mathrm{C}$ was used to inoculate flasks containing Soll's Medium either at $\mathrm{pH} 4.5$ and $25^{\circ} \mathrm{C}, \mathrm{pH} 4.5$ and $37^{\circ} \mathrm{C}, \mathrm{pH} 6.5$ and $25^{\circ} \mathrm{C}$, or $\mathrm{pH} 6.5$ and $37^{\circ} \mathrm{C}$. Cell morphology and TEF3 and ACT1 mRNA levels were then determined as described in (a). The radioactive signals obtained on the filters shown in (a) and (b) were quantified directly by 2D-radioimaging and the data are presented in (c) and (d), respectively.

established, it displays ribosome-dependent GTPase and ATPase activities (Dasmahapatra \& Chakraburtty, 1981; Miyazaki et al., 1988; Skogerson \& Wakatama, 1976) and it might play a role in maintaining the accuracy of mRNA decoding at the ribosomal A-site (Belfield \& Tuite, 1993). EF-3 represents an attractive antifungal target because it is essential for translation in fungi, but not in mammalian systems.

A previous analysis of TEF3 expression in C. albicans suggested that there is no significant difference in the level of the TEF3 mRNA in the yeast and hyphal forms (DiDomenico et al., 1992). This suggested that TEF3 mRNA levels may provide a useful loading control in Northern analysis of other mRNAs during the dimorphic transition. Actin mRNA ( $A C T 1)$ levels which are normally used in other systems, change during morphogenesis (Lasker \& Riggsby, 1992; Paranjape \& Datta, 1991; Delbrück \& Ernst, 1993). Therefore, in this study we have sought to clarify the influence of dimorphism on TEF3 gene expression.

\section{METHODS}

Strains and culture conditions. Candida albicans Robin (Berkhout) strain 3153 from the London Mycological Reference Laboratory was used throughout. The dimorphic transition was induced using two different experimental conditions. C. albicans was grown in the yeast form to late-exponential growth phase at $25{ }^{\circ} \mathrm{C}$ with shaking at 200 r.p.m. in YPD [ $2 \%(w / v)$ glucose, $2 \%(\mathrm{w} / \mathrm{v})$ bacteriological peptone, $1 \%(\mathrm{w} / \mathrm{v})$ yeast extract]. To induce hyphal growth, $10 \mathrm{ml}$ of this culture was then used to inoculate (approximately $2 \times 10^{7}$ cells $\mathrm{ml}^{-1}$ ) $100 \mathrm{ml}$ of YPD containing $10 \%(\mathrm{v} / \mathrm{v})$ bovine calf serum at $37^{\circ} \mathrm{C}$ and samples were removed at various times up to $120 \mathrm{~min}$. Control cultures were grown in fresh YPD at $25^{\circ} \mathrm{C}$ without serum, $25^{\circ} \mathrm{C}$ with serum, and $37^{\circ} \mathrm{C}$ without serum. Alternatively, C. albicans was grown in the yeast form to late-exponential growth phase in Soll's Medium at $25^{\circ} \mathrm{C}$ and $\mathrm{pH} 4.5$ with shaking at 200 r.p.m. and hyphal growth was induced by inoculating $10 \mathrm{ml}$ of this culture (approximately $2 \times 10^{7}$ cells $\mathrm{ml}^{-1}$ ) into $100 \mathrm{ml}$ Soll's Medium at $37^{\circ} \mathrm{C}$ and $\mathrm{pH} 6.5$ (Soll, 1986) and samples were removed at various times up to $180 \mathrm{~min}$. Control cultures were grown in fresh Soll's Medium at $25^{\circ} \mathrm{C}$ and $\mathrm{pH} 4.5,25^{\circ} \mathrm{C}$ and $\mathrm{pH} 6.5$, and $37^{\circ} \mathrm{C}$ and $\mathrm{pH} 4.5$. Soll's Medium is the defined 
medium of Lee et al. (1975) modified according to Buffo et al. (1984). Cell numbers and morphology were monitored by light microscopy. Cell numbers were measured by light microscopy using an improved Neubauer haemocytometer. At least 200 cells were counted at each time point (errors $<10 \%$ ).

RNA isolation and Northern blotting. Total RNA was prepared from C. albicans using the procedures of Lindquist (1981). Northern analysis was performed as described previously (Moore et al., 1991) using radiolabelled probes prepared by random-priming of purified DNA restriction fragments (Feinberg \& Vogelstein, 1983). A 0.7 kbp fragment representing coordinates $126-829$ bp of the $C$. albicans TEF 3 coding region (cloned in pUC19; Colthurst et al., 1992) and the $1.5 \mathrm{kbp}$ Bam HI-HindIII fragment of the S. cerevisiae ACT1 gene (cloned in pSP65; Bettany et al., 1989) were used as probes. Hybridizations were performed under conditions of excess probe, and signals were quantified directly by $2 \mathrm{D}$-radioimaging using an AMBIS Radioanalytic System (LabLogic). No internal mRNA loading control is available for $C$. albicans. Therefore, mRNA levels were measured relative to the ribosomal RNAs by loading approximately equal amounts of total RNA in each lane of the gels. Bound probes were removed by washing the filters in boiling $0 \cdot 1 \%(\mathrm{w} / \mathrm{v})$ SDS, and the filters were probed sequentially for the TEF3 and $A C T 1 \mathrm{mRNAs}$ to allow direct comparison of expression patterns. Other DNA and RNA manipulations were performed according to standard procedures (Sambrook et al., 1989).

Western blot analysis. Protein extracts (Hostetter et al., 1990) were electrophoresed on SDS-10\% (w/v) polyacrylamide gels (Laemmli, 1970), electroblotted onto nitrocellulose membranes, and the EF-3 polypeptide detected using an anti-EF-3 polyclonal antibody (Colthurst et al., 1991). The secondary antibody was alkaline-phosphatase-conjugated anti-rabbit IgG (Sigma).

\section{RESULTS}

\section{TEF3 mRNA levels during morphogenesis}

TEF 3 mRNA levels were measured during the yeast-tohyphal transition under two different sets of growth conditions (Fig. 1). Hyphal growth was induced using (i) an increase in growth temperature $\left(25\right.$ to $\left.37^{\circ} \mathrm{C}\right)$ combined with the addition of bovine calf serum to the medium, or (ii) an increase in growth temperature $\left(25\right.$ to $37^{\circ} \mathrm{C}$ ) combined with an increase in the $\mathrm{pH}$ of the medium ( $\mathrm{pH} 4.5$ to 6.5 ). Under each set of conditions several parameters were altered to induce the transition, and therefore additional cultures were included to control for the effects of temperature, serum or $\mathrm{pH}$ (Fig. 1). In both experimental protocols an increase in temperature alone induced a low level of germ tube formation (Fig. 1a, b), but these levels never reached those achieved under optimal conditions using (i) a temperature increase plus serum or (ii) a temperature increase plus a $\mathrm{pH}$ change. The levels of the $T E F 3 \mathrm{mRNA}$ were relatively low in the lateexponential cells in the starter culture, but they increased rapidly upon dilution of these cells into fresh medium. This increase occurred over the first 20-60 min depending upon the growth conditions. During growth at $25^{\circ} \mathrm{C}$ TEF 3 mRNA levels remained at relatively high levels over the time period analysed, whereas at $37^{\circ} \mathrm{C}, T E F 3$ mRNA levels decreased after about 20-30 min (Fig. 1c, d). The decline was faster in cultures which showed a higher induction of germ tubes or hyphae. This pattern, which was reproducible, was not influenced significantly by the use of a medium that was rich or defined, at $\mathrm{pH} 4.5$ versus $\mathrm{pH} 6.5$, or whether it contained serum or not. Therefore, TEF3 mRNA levels changed during the dimorphic transition under the experimental conditions analysed, but did not correlate absolutely with morphogenesis per se.

The ACT1 mRNA is frequently used as a control in $S$. cerevisiae (e.g. Moore et al., 1991). Therefore, we measured the levels of the $A C T 1 \mathrm{mRNA}$ under our experimental conditions (Fig. $1 \mathrm{c}, \mathrm{d}$ ), but $A C T 1 \mathrm{mRNA}$ levels have

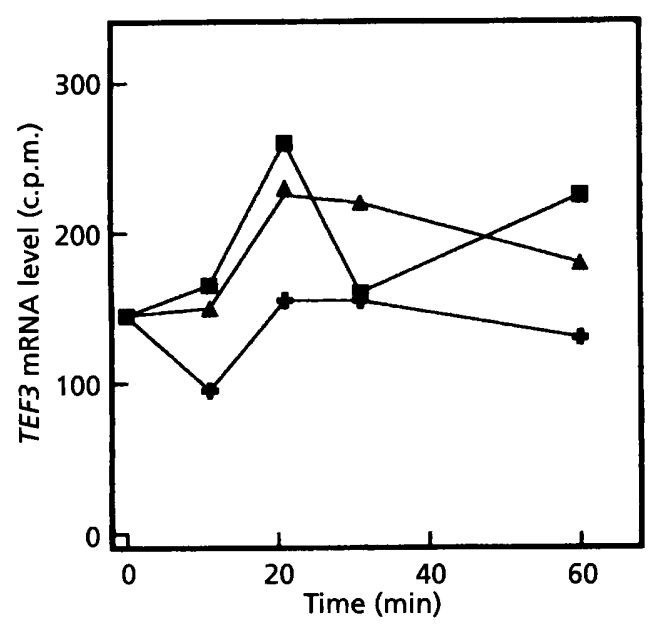

Fig. 2. Effect of heat-shock on TEF3 mRNA levels. An earlyexponential culture of $\mathrm{C}$. albicans grown in YPD at $25^{\circ} \mathrm{C}$ was

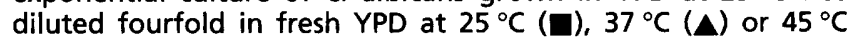
$(+)$; the cultures were held at these temperatures for $10 \mathrm{~min}$, and then incubated at $25^{\circ} \mathrm{C}$ (time $=0 \mathrm{~min}$ ). RNA was prepared from each culture at various times thereafter, and the level of the TEF3 mRNA determined by Northern analysis using 2Dradioimaging to quantify signals directly on the filter. Cells grew in the yeast form throughout the experiment.

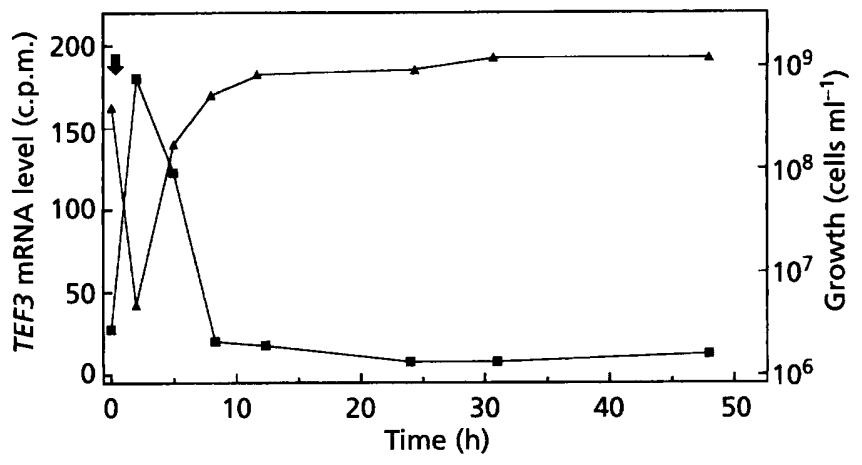

Fig. 3. TEF3 mRNA levels during batch growth of the yeast form in YPD at $25^{\circ} \mathrm{C}$. An overnight starter culture of $C$. albicans was used to inoculate fresh culture of YPD (arrow). The culture was incubated at $25^{\circ} \mathrm{C}$ with shaking (200 r.p.m.) and growth (A) monitored by light microscopy. TEF3 mRNA levels ( $\square$ ) were measured by quantitative Northern analysis. Points at time $=0$ represent cell counts and TEF3 mRNA levels immediately before dilution into fresh medium. 


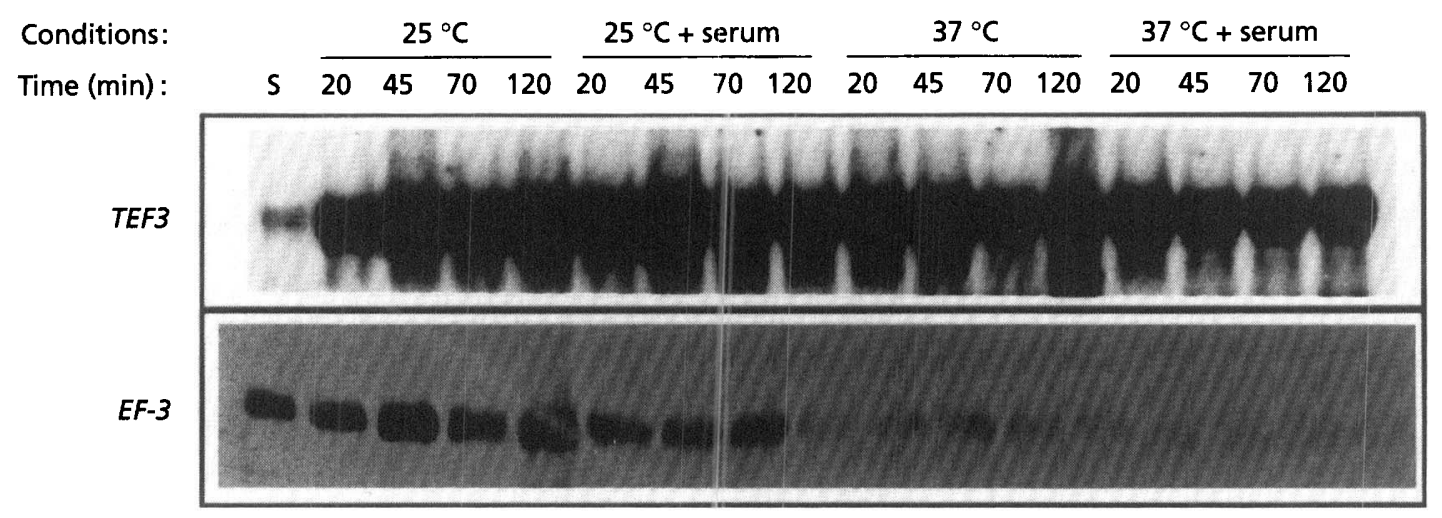

Fig. 4. Comparison of EF-3 and TEF3 mRNA levels under different growth conditions. The yeast-to-hyphal transition was induced by an increase in culture temperature and the addition of bovine calf serum, and control cultures set up as described for Fig. 1(a). EF-3 was detected by Western blotting and compared with TEF3 mRNA levels under similar growth conditions (Northern data taken from Fig. 1a). S, Starter culture.

been shown to change during morphogenesis in C. albicans (Lasker \& Riggsby, 1992; Paranjape \& Datta, 1991; Delbrück \& Ernst, 1993). Consistent with previous reports, ACT1 mRNA levels increased upon dilution of late-exponential cells into fresh medium, thus validating the observed increase in TEF 3 mRNA levels. However, the patterns of $A C T 1$ and TEF 3 expression differed in that the rate of increase in the $A C T 1$ mRNA level following dilution into fresh medium was slower in the cultures at $25^{\circ} \mathrm{C}$ compared with $37^{\circ} \mathrm{C}$. The ratio of the TEF 3 to ACT1 mRNA level did not remain constant under the conditions studied.

\section{The effect of heat-shock on TEF3 mRNA levels}

To separate the influence of the temperature increase from that of the dimorphic transition, cells were heat-shocked under conditions which do not induce the dimorphic switch. Heat-shock at $37^{\circ} \mathrm{C}$ or $45^{\circ} \mathrm{C}$ did not affect TEF 3 mRNA levels to any great extent (Fig. 2).

\section{TEF3 mRNA levels during batch growth}

The patterns of expression observed for TEF 3 in Fig. 1 indicated that this gene might be responding to changes in growth. To test this, cells from a late-exponential culture were diluted 50 -fold into fresh YPD at $25^{\circ} \mathrm{C}$, and TEF3 mRNA levels measured at various times during the growth of the yeast form (Fig. 3). TEF3 mRNA levels increased rapidly upon dilution into fresh medium, reached their maximal levels during the exponential growth phase, and declined to low levels during the transition and stationary phases. Therefore, TEF3 expression is regulated during batch growth, and might be related to cell growth rate.

\section{Comparison of EF-3 and TEF3 mRNA levels}

Some C. albicans genes appear to be subject to posttranscriptional regulation (Mason et al., 1993). Therefore, the level of the EF-3 polypeptide was analysed by Western blotting and compared with TEF 3 mRNA levels under the same conditions (Fig. 4). The EF-3 polypeptide of molecular mass about $130 \mathrm{kDa}$ was detected by Western blot analysis under all the conditions tested, although the levels were lower during growth at $37^{\circ} \mathrm{C}$ compared with $25^{\circ} \mathrm{C}$. This was reasonably consistent with the observed TEF 3 mRNA levels. However, in contrast to the TEF3 mRNA, the EF-3 polypeptide was relatively abundant in late-exponential cells (in the starter culture), and EF-3 levels appeared to decrease when these cells were diluted into fresh media under some conditions (Fig. 4). This difference in TEF3 mRNA and EF-3 levels was reproducible. Therefore, TEF 3 expression appears to be modulated at a post-transcriptional level(s).

\section{DISCUSSION}

A previous analysis of TEF3 gene expression in $C$. albicans suggested that the abundance of its mRNA was similar in the yeast and hyphal forms when measured relative to the ACT1 mRNA (DiDomenico et al., 1992). However, $A C T 1$ mRNA levels are known to change during the yeast-to-hyphal transition in C. albicans (Lasker \& Riggsby, 1992; Paranjape \& Datta, 1991; Delbrück \& Ernst, 1993), and therefore in this study we investigated $T E F 3$ expression in more detail with a view to testing the possibility of using this mRNA as a loading control in studies of dimorphic gene regulation. We measured TEF 3 $\mathrm{mRNA}$ levels relative to the ribosomal RNAs as a loading control in the Northern blots. TEF3 mRNA levels changed during the dimorphic transitions under the two different experimental conditions analysed, but there was no strict correlation between TEF $3 \mathrm{mRNA}$ levels and the rate of germ tube formation (Fig. 1). It should be noted, however, that there may be a potential influence of hyphal development on TEF3 expression since the rate of decrease in TEF3 mRNA levels after 20-30 min was more rapid in those cultures forming germ tubes (Fig. 1). TEF3 mRNA levels were not significantly affected by the presence or absence of serum in the medium, or by the $\mathrm{pH}$ of the medium (Fig. 1). Also, TEF3 mRNA levels were 
not dramatically affected by heat-shock under conditions which did not permit germ tube formation (Fig. 2). However, the expression of the gene was tightly regulated during batch growth of the yeast form, with maximal $T E F 3$ mRNA levels being observed during the early exponential growth phase (Fig. 3). Therefore, the fluctuations in TEF3 mRNA levels appear to reflect the underlying changes in cell cytology and physiology that accompany morphogenesis (Gow et al., 1986; Gow \& Gooday, 1987; Odds, 1988; Stewart et al., 1988) and not necessarily morphogenesis per se. The fact that the levels of the actin, chitin synthase 1, chitin synthase 2, pyruvate kinase and alcohol dehydrogenase mRNAs also change during the dimorphic transition (Chen-Wu et al., 1992; Lasker \& Riggsby, 1992; Paranjape \& Datta, 1991; Delbrück \& Ernst, 1993; Swoboda et al., 1993) would seem to support this view. Interestingly, the levels of the TEF1 and TEF $2 \mathrm{mRNAs}$, which encode identical EF-1 $\alpha$ polypeptides, appear to be similar in yeast and hyphal cells (Sundstrom et al., 1991). However, no detailed kinetic analysis of these mRNAs was performed during the dimorphic transition, and therefore it is possible that these mRNAs behave in a similar fashion to the TEF3 mRNA. This would present a technical problem in that, to our knowledge, none of the $C$. albicans mRNAs studied to date have been shown to remain at constant levels during the dimorphic transition and hence no internal mRNA loading control is available for Northern analysis under these conditions. This study shows that the TEF $3 \mathrm{mRNA}$ is not a suitable loading control for such studies.

The abundance of the EF-3 polypeptide did not always mirror the TEF3 mRNA level under the conditions tested (Fig. 4). For example, EF-3 appeared to be relatively abundant in late-exponential cells when the TEF $3 \mathrm{mRNA}$ was at low levels, and the polypeptide was not abundant during growth at $37^{\circ} \mathrm{C}$ when TEF 3 mRNA levels were elevated. This might indicate that TEF3 expression is subject to post-transcriptional regulation. Differential rates of TEF3 mRNA translation, modulation of EF-3 stability, or combination of these factors could account for this observation. Interestingly the $C$. albicans enolase gene might also be regulated at a post-transcriptional level (Mason et al., 1993). However, it should be noted that the observed changes in the abundance of the EF-3 polypeptide might not reflect the activity in vivo of this essential, fungal-specific translation factor under all experimental conditions.

\section{ACKNOWLEDGEMENTS}

This work was supported by grants from The Wellcome Trust (research grant no. 031097) and the Oral and Dental Research Trust.

\section{REFERENCES}

Belfield, G. P. \& Tuite, M. F. (1993). Translation elongation factor 3: a fungus-specific translation factor? Mol Microbiol 9, 411-418.

Bettany, A. J. E., Moore, P. A., Cafferkey, R., Bell, L. D., Goodey, A. R., Carter, B. L. A. \& Brown, A. J.P. (1989). 5'-Secondary structure formation, in contrast to a short string of non-preferred codons, inhibits the translation of the pyruvate kinase mRNA in yeast. Yeast 5, 187-198.

Buffo, J., Herman, M. A. \& Soll, D. R. (1984). A characterization of $\mathrm{pH}$ regulated dimorphism in Candida albicans. Mycopatbologia 85, 21-30.

Chakraburtty, K. \& Kamath, A. (1988). Protein synthesis in yeast. Int J Biochem 20, 581-590.

Chen-Wu, J. L., Zwicker, J., Bowen, A. R. \& Robbins, P. W. (1992). Expression of chitin synthase genes during yeast and hyphal growth phases of Candida albicans. Mol Microbiol 6, 497-502.

Colthurst, D. R., Santos, M., Grant, C. M. \& Tuite, M. F. (1991). Candida albicans and three other Candida species contain an elongation factor structurally and functionally analogous to elongation factor 3. FEMS Microbiol Lett 80, 45-50.

Colthurst, D. R., Schauder, B. S., Hates, M. V. \& Tuite, M. F. (1992). Elongation factor 3 (EF-3) from Candida albicans shows both structural and functional similarity to EF-3 from Saccharomyces cerevisiae. Mol Microbiol 6, 1025-1033.

Cutler, J. E. (1991). Putative virulence factors of Candida albicans. Annu Rev Microbiol 45, 187-218.

Dasmahapatra, B. \& Chakraburtty, K. (1981). Protein synthesis in yeast: 1. Purification and properties of elongation factor 3 from Saccharomyces cerevisiae. J Biol Chem 256, 9999-10004.

Delbrück, S. \& Ernst, J. F. (1993). Morphogenesis-independent regulation of actin transcript levels in the pathogenic yeast $C$ andida albicans. Mol Microbiol 10, 859-866.

DiDomenico, B. J., Lupisella, J., Sandbaken, M. \& Chakraburtty, K. (1992). Isolation and sequence analysis of the gene encoding translation elongation factor 3 from Candida albicans. Yeast 8 , 337-352.

Feinberg, A. P. \& Vogelstein, B. (1983). A technique for radiolabelling DNA restriction endonuclease fragments to high specific activity. Anal Biochem 132, 6-13.

Gow, N. A. R. \& Gooday, G. W. (1987). Cytological aspects of dimorphism in Candida albicans. Crit Rev Microbiol 15, 73-78.

Gow, N. A. R., Henderson, G. \& Gooday, G. W. (1986). Cytological interrelationships between the cell cycle and duplication cycle of Candida albicans. Microbios 47, 97-105.

Hinnebusch, A. G. \& Liebman, S. W. (1991). Protein synthesis and translational control in Saccharomyces cerevisiae. In The Molecular Biology of the Yeast, Saccharomyces: Genome Dynamics, Protein Synthesis and Energetics, vol. 1, pp. 627-735. Edited by J. R. Broach, J. R. Pringle \& E. W. Jones. Cold Spring Harbor, NY: Cold Spring Harbor Laboratory Press.

Hostetter, M. K., Lorenz, J. S., Preus, L. \& Kendrich, K. E. (1990). The iC3b receptor on Candida albicans: subcellular localization and modulation of receptor expression by glucose. J Infect Dis 161, $761-768$

Laemmli, U. K. (1970). Cleavage of structural proteins during the assembly of the head of bacteriophage T4. Nature 227, 680-685.

Lasker, B. A. \& Riggsby, W. S. (1992). Transcription of the single actin gene of Candida albicans during the yeast-to-mycelium transition. Exp Mycol 16, 155-162.

Lee, K. L., Buckley, H. R. \& Campbell, C. C. (1975). An amino acid liquid synthetic medium for the development of mycelial and yeast forms of Candida albicans. Sabouraudia 13, 148-153.

Lindquist, S. (1981). Regulation of protein synthesis during heat shock. Nature 293, 311-314.

Mason, A. B., Buckley, H. R. \& Gorman, J. A. (1993). Molecular cloning and characterization of the Candida albicans enolase gene. $J$ Bacteriol 175, 2632-2639. 
Merrick, W. C. (1992). Mechanism and regulation of eukaryotic protein synthesis. Microbiol Rev 56, 291-315.

Miyazaki, M., Uritani, M. \& Kagiyama, H. (1988). The yeast peptide elongation factor 3 (EF-3) carries an active site for ATP hydrolysis which can interact with various nucleoside triphosphates in the absence of ribosomes. $J$ Biochem 104, 445-450.

Moore, P. A., Sagliocco, F. A., Wood, R. M. C. \& Brown, A. J. P. (1991). Yeast glycolytic mRNAs are differentially regulated. Mol Cell Biol 11, 5330-5337.

Nygard, O. \& Nilsson, L. (1990). Translational dynamics: interactions between the translation factors, tRNA and ribosomes during eukaryotic protein synthesis. Eur J Biochem 191, 1-17.

Odds, F. C. (1985). Morphogenesis in Candida albicans. Crit Rev Microbiol 12, 45-93.

Odds, F. C. (1988). Candida and Candidosis: a Review and Bibliography. (2nd edn). London: Bailliere Tindall.

Paranjape, V. \& Datta, A. (1991). Overexpression of the actin gene is associated with the morphogenesis of Candida albicans. Biocbem Biopbys Res Commun 179, 423-427.

Ryley, J. F. \& Ryley, N. G. (1990). Candida albicans - do mycelia matter? J Med Vet Mycol. 28, 225-239.

Sambrook, J., Fritsch, E. F. \& Maniatis, T. (1989). Molecular Cloning: a Laboratory Manual, 2nd edn. Cold Spring Harbor, NY: Cold Spring Harbor Press.

Sherwood, J., Gow, N. A. R., Gooday, G. W., Gregory, D. W. \& Marshall, D. (1992). Contact sensing in Candida albicans: a possible aid to epithelial penetration. $J$ Med Vet Mycol 30, 461-469.
Skogerson, L. \& Wakatama, E. (1976). A ribosome-dependent GTPase from yeast distinct from elongation factor 2. Proc Natl Acad Sci US A 73, 73-76.

Soll, D. R. (1986). The regulation of cellular differentiation in the dimorphic yeast Candida albicans. BioEssays 5, 5-11.

Stewart, E., Gow, N. A. R. \& Bowen, D. V. (1988). Cytoplasmic alkalinization during germ tube formation in Candida albicans. $J \mathrm{Gen}$ Microbiol 134, 1079-1087.

Sundstrom, P., Irwin, M., Smith, D. \& Sypherd, P. S. (1991). Both genes for EF-1 $\alpha$ in Candida albicans are translated. Mol Microbiol 5, 1703-1706.

Swoboda, R. K., Bertram, G., Hollander, H., Greenspan, D., Greenspan, J. S., Gow, N. A. R., Gooday, G. W. \& Brown, A. J. P. (1993). Glycolytic enzymes of Candida albicans are nonubiquitous immunogens during candidiasis. Infect Immun 61, 4263-4271.

Tuite, M. F. (1989). Protein synthesis. In The Yeasts vol. 3, pp. 161-204. Edited by A. H. Rose \& J. S. Harrison. London: Academic Press.

Uritani, M. \& Miyazaki, M. (1988). Characterization of the ATPase and GTPase activities of elongation factor 3 (EF-3) purified from yeasts. $J$ Biochem 103, 522-530.

Ypma-Wong, M. F., Fonzi, W. A. \& Sypherd, P. S. (1992). Fungusspecific translation elongation factor 3 gene present in Pneumocystis carinii. Infect Immun 60, 4140-4145.

Received 7 March 1994; revised 13 May 1994; accepted 31 May 1994. 